\title{
Britain releases green bill
}

\section{London}

A NEW method to measure pollution from Britain's dirtiest factories and legislation on the release of genetically engineered organisms are outlined in the government's wide-ranging environmental protection bill, published just before Christmas. The bill, popularly known as the 'green bill', deals with a collection of issues that have accumulated at the Department of the Environment over the past decade.

The bill introduces integrated pollution control (IPC) which will require the effect of pollutant emissions to air, land and water to be assessed together, rather than separately as at present. Some 3,500 industrial sites will be covered by IPC and will have to obtain and pay for authori-

\section{COMPUTER MISUSE}

\section{Strict law proposed}

\section{London}

Tough new penalties for computer crime are proposed in a private member's bill presented to the British parliament. The bill, introduced by Conservative Member of Parliament Michael Colvin, would define three new crimes. The first is a 'basic' offence of unauthorized access to a computer system which would be punishable by a maximum fine of $£ 2,000$ and/or six months' imprisonment. Two more serious offences, unauthorized entry into a system with intent to commit a crime and unauthorized alteration of computer-held information (including the circulation of disks carrying computer 'viruses' and other destructive programs), would carry a maximum penalty of five years' imprisonment.

Colvin's bill follows the recommendations of an earlier Law Commission report but doubles the penalties for the basic offence of unauthorized entry, or hacking. The Law Commission report arrived too late for its suggestions to be presented as a government bill this year, and Colvin believes that the problem of computer misuse demands urgent action, if Britain is not to become an "international centre for computer crime". Estimates of the financial cost of computer crime in Britain vary between $£ 400$ million and $£ 1,000$ million a year. Colvin says the decision to propose the bill was influenced by the recent outcry over the distribution of a 'trojan horse' program, disguised as information on AIDS, to thousands of British computer users.

Private members' bills have great difficulty in becoming law because it is hard to find time for them in the parliamentary schedule. But Colvin is optimistic. The bill will be debated in detail at its second reading in the House of Commons on 9 February.

PeterAldhous

zations to operate from Her Majesty's Inspectorate of Pollution (HMIP). Authorizations will demand that factories use the "best available techniques not entailing excessive cost" to render emissions harmless. Contravention of the specific conditions contained in authorizations may be punished by an unlimited fine. A second tier of less-polluting factories would not be subject to IPC, but the government intends to give local authorities new powers to control industrial air pollution.

Chris Patten, Secretary of State for the Environment, claims that the bill creates "foundations for pollution control well into the next century". But there is concern that HMIP will not have the manpower to police the new IPC controls. A recruitment drive is under way to fill 33 vacancies and it is hoped that recent pay rises will help to relieve a crisis of morale within the inspectorate. At a press conference, Patten said that the current recruitment drive may precede a strengthening of HMIP.

New controls on the release of genetically manipulated organisms are also contained in the bill. They will implement some of the recommendations from the Royal Commission on Environmental Pollution report, published in July (see Nature 340, 84; 13 July 1989). Those seeking to release genetically manipulated organisms will need to provide an assessment of the environmental hazards posed by the release, and must then wait for consent to be granted by the Health and Safety Commission (HSC) and the Secretary of State for the Environment (in some cases, the Ministry of Agriculture may also be involved).

But, as indicated in a government consultation paper released in June, some releases may be exempt from the system of consents. The precise criteria by which exemptions are to be granted will become clear only as the bill is debated in parliament. Another area to be clarified is the extent to which the content of applications for consents will be made public.

The new regulations will complement existing legislation that stresses human health and safety, rather than environmental protection. That legislation is enforced by the Health and Safety Executive (the operating arm of the HSC) with help from the Advisory Committee on Genetic Manipulation. Under the new proposals, the advisory committee would continue its function, and a new committee would advise the Health and Safety Commission and the environment secretary on the environmental implications of the release of genetically manipulated organisms. A single consent for each release would then be granted on the basis
Scientist as science minister

New Delhi

Prime Minister Vishwanath Pratap Singh, whose National Front party came to power in the recent Indian election, pulled a surprise at the end of last year by appointing Professor M.G.K. Menon as the minister for science. Menon had held scientific posts in Congress-led governments since 1971 and was science adviser to the former Prime Minister Rajiv Gandhi.

Menon was an associate of Homi Bhabha, father of India's atomic energy programme, and is a well-known cosmicray physicist. He said the appointment came as a surprise. $\mathrm{He}$ is the first scientist to become science minister in independent India. His predecessors were all diplomats or elected politicians. In choosing Menon for the job, Singh, himself a physicist, was guided by his philosophy that science is non-political and that a professional is needed to steer India's vast scientific establishment.

As a member of the planning commission since 1983, Menon was in charge of formulating five-year science plans and allocation of funds for various departments. Before that, he had served as secretary in the departments of electronics, defence research, science and technology and environment. He was chairman of the UN secretary general's committee for science and technology for development. He has been president of the International Council of Scientific Unions since 1986.

Menon said his first task would be to integrate the multiplicity of departments and improve links between research, industry and education.

He expects some changes in research priorities but has ruled out any major shift. "We cannot pull back programmes already committed", he said, "but we can always review the phasing of these." K. S. Jayaraman

of both human health and environmental considerations.

Also included in the 'green bill' are new rules on the dumping of waste at sea and waste disposal by local authorities and increased penalties for littering. While welcoming some of its proposals, the Labour opposition and environmental pressure groups have attacked the bill for being a "hotchpotch" of unconnected measures, and for its proposal to split the government's advisory body on conservation issues, the Nature Conservancy Council, into separate agencies for England, Scotland and Wales. Also criticized is the failure to include controls on the emission of carbon dioxide. Future government policy on this and other environmental issues will become apparent in a white paper (policy document) to be published next autumn. Peter Aldhous 